\title{
GEOGRAPHY LITERACY OF OBSERVATION INTRODUCTION LANDSCAPE REPRESENTATION PLACE FOR STUDENT EXPERIENCE (Ethnomethodology Perspective)
}

\author{
Fahrudi Ahwan Ikhsan', Fahmi Arif Kurnianto ${ }^{2}$, Bejo Apriyanto ${ }^{3}$, Elan Artono Nurdin ${ }^{4}$ \\ ${ }^{1,2,3,4}$ Department of Geography Education, University of Jember, Indonesia \\ Email: ahwan.fkip@unej.ac.id
}

Received: 23 June 2018/Revised: 7 July 2018/Accepted: 18 August 2018/Published online: 28 August 2018

\begin{abstract}
This study aims to describe the understanding of geography literacy and student experience with landscape recognition observations using an ethnometodology perspective. The subject of this study was the chairman of each landscape recognition practice group student geography education program from University of Jember. The results of this study that geography literacy has a dimension of relevance to geographic skills in representing contextual phenomena and places from landscape recognition observation activities. The results of both observational studies provide research experience, motivation, critical and scientific thinking skills for students represented in the mapping of the area.
\end{abstract}

Keywords: Geography Literacy, Student Experience, Ethnometodology

\section{Introduction}

Geography education is needed in understanding the phenomena, location, and world for prespective geographers. Geography literacy has an influence to explain physical information and human activities. Geography literacy skills are needed in the observation of landscape recognition. Turner and Leydon (2012), explained that literacy geography skills are very valuable for students in connecting the concepts and theories that are being learned at this time throughout the world. The component of spatial literacy in geography includes component of the concept of space, representational tools, and thought processes (NRC, 2006). Students must be able to visualize the geospatial distribution of culture, economics and natural resources to understand the complexity of the environment globally (Guertin et al., 2012). Knowledge geography literacy is used to understand, process, and utilize spatial data (Turner and Leydon, 2012).

The implementation of geography literacy is significantly influential in building spatial knowledge of students. Every individual has a different structure in processing 
information and spatial thinking ability in the neurological system (Levinson, 2003). One method of observation that can be used to analyze geographic phenomena contextually in the learning of spatial literacy. Field observation activities in the introduction of landscapes are more centered on student activity. An integral component of the observation approach taken by students requires lecturers as facilitators and controls in the learning process (Chappell, 2007). Relations in observation activities will build communication between lecturers and students. Reflective participation and attitudes need to be shown by lecturers to students in providing an understanding of the introduction of landscapes.

The experience student from the practice of landscape recognition lectures serves to provide a reality picture of geographic phenomena occurring on the surface of the earth. The results of reflection from practice can build students' cognitive, affective, and psychomotor skills. Geography literacy in the observation landscape recognition requires high-level skills. Cotton et. al (2010), stated that geographic observation methods can provide selective, rational experience and behavior as well as arguments from observations. Special attention to observation methods of aspects affective experience in particular include attitudes, motivation, and student responses (Boyle et.al, 2007; Stokes \& Boyle, 2009).

The purpose of this study was to determine the experience of student literacy geography in landscape recognition practices as a representation of places. The studies observed include physical phenomena and human activities in an integrated manner. The experience of students' geography literacy of landscape recognition practices was identified from their participation during observation activities.

\section{The Methods}

The method used in this research is qualitative with ethnometodology approach. This approach is used to understand the natural actions of a particular ethnic group, the study includes social agents of the community, understand their lives (a group of human life), and how they are sustained every day when interacting with their groups (Fatchan, 2015). Qualitative researchers aim to develop strategies and procedures by considering experience from the perspective of informants (Bogdan \& Biklen, 1998). Qualitative research provides an opportunity to develop understanding of subject matter well (Denzin \& Lincoln, 2008).

The subject of this study was the head of the landscape learning field practice group as many as 8 students. The information studied is distinguished the reasons: (1) Geography literacy understanding of students in the practice of landscape recognition observation lectures which are represented in the volcanology area of the Bromo Mountain in 
Probolinggo Region; and (2) The experience gained by students from the observation of landscape recognition as a representation of a place in the volcanology area of Mount Bromo, Probolinggo Region. Individual experiences and insights are an important part of inquiry and critical thinking to understanding the information from interviews (Patton, 2002).

Data collection techniques are carried out by interviewing and documenting the research subject in depth. The informants in this study were students who took part in a landscape recognition introduction practice program in the volcanology area of the Bromo Mountain in Probolinggo Region. Data from the interviews were analyzed descriptively with the coding matrix of the informants. The coding technique is used to explore and connect between codes with each other. Themes and concepts are interpreted to prepare final reports in research (Miles, Huberman, \& Saldana, 2015)

\section{Results and Discussion}

The informants in this study were taken from the chair landscape recognition practice group student of Geography Education Program in University Jember. Researchers choose informants according to activities the field in assessing geographic locations and phenomena. Researchers get informant with direct interviews with 8 selected students including: (1) Rislianta Alsabila (RA); (2) Cindy Eka Pratiwi (CEP); (3) Achmad Dwi Kurniawan (ADK); (4) Eva Kurniasari (EK); (5) Aisyah Widatul Khoiroh (AWK); (6) Moh. Fajar Septarianto (MFS); (7) Shandy Choirul Fatah (SCF); dan (8) Arum Cahyaning Utami (ACU). The eight informants provided data in the study with the following explanation:

Table 1: Geography Literacy in Practical Observation of Field Learning Introducation Landscape Recognition in Bromo Mountain Probolinggo Regency

\begin{tabular}{|c|c|c|c|}
\hline No. & $\begin{array}{l}\text { Name of } \\
\text { Informant }\end{array}$ & Information & The Theme Found \\
\hline \multirow[t]{3}{*}{1.} & $\begin{array}{c}\text { Rislianta } \\
\text { Alsabila (RA) }\end{array}$ & $\begin{array}{l}\text { 1. "The definition and essence of } \\
\text { geography becomes difficult to } \\
\text { understand when learning in } \\
\text { class" }\end{array}$ & $\begin{array}{l}\text { 1. Feeling an } \\
\text { understanding of the } \\
\text { concept of geography }\end{array}$ \\
\hline & & $\begin{array}{l}\text { 2. "I understand the use of } \\
\text { geographic principles and } \\
\text { concepts in accordance with the } \\
\text { facts in the field" }\end{array}$ & $\begin{array}{l}\text { 2. Easy application in the } \\
\text { field }\end{array}$ \\
\hline & & $\begin{array}{l}\text { 3. "Understanding of natural and } \\
\text { human phenomena can be } \\
\text { studied in an integrated } \\
\text { manner" }\end{array}$ & $\begin{array}{l}\text { 3. Studying geography } \\
\text { needs as a whole }\end{array}$ \\
\hline
\end{tabular}




\begin{tabular}{|c|c|c|c|}
\hline & & $\begin{array}{l}\text { 4. "The geographic phenomenon } \\
\text { is influenced by the location } \\
\text { and place that distinguishes } \\
\text { compared to other regions" } \\
\text { 5. "Landscape recognition } \\
\text { introduction activities need to } \\
\text { understand the geosphere study } \\
\text { for all" }\end{array}$ & $\begin{array}{l}\text { 4. Regional differences } \\
\text { affect geographic } \\
\text { understanding }\end{array}$ \\
\hline & & $\begin{array}{l}\text { 6. "Observation of landscape } \\
\text { recognition uses more } \\
\text { applications of concepts and } \\
\text { principles from geography" }\end{array}$ & $\begin{array}{l}\text { 6. Theories about } \\
\text { geographic concepts } \\
\text { and principles are } \\
\text { needed in the field }\end{array}$ \\
\hline \multirow[t]{8}{*}{2.} & $\begin{array}{c}\text { Cindy Eka } \\
\text { Pratiwi (CEP) }\end{array}$ & $\begin{array}{l}\text { 1. "Geography literacy in its } \\
\text { application in the field requires } \\
\text { an understanding of spatial } \\
\text { thinking" }\end{array}$ & $\begin{array}{l}\text { 1. The implementation of } \\
\text { geographic literacy is } \\
\text { influenced by spatial } \\
\text { thinking skills }\end{array}$ \\
\hline & & $\begin{array}{l}\text { 2. "Geography literacy builds on } \\
\text { geographic thinking in } \\
\text { interpreting phenomena, spaces } \\
\text { and locations to study territory" }\end{array}$ & $\begin{array}{l}\text { 2.Studying the region } \\
\text { needs to master } \\
\text { geographic literacy }\end{array}$ \\
\hline & & $\begin{array}{l}\text { 3. "I feel the application of field } \\
\text { observation is easier in } \\
\text { providing knowledge and } \\
\text { understanding of geography } \\
\text { studies" }\end{array}$ & $\begin{array}{l}\text { 3. Understanding and } \\
\text { knowledge are more } \\
\text { easily obtained from } \\
\text { the results of field } \\
\text { practice }\end{array}$ \\
\hline & & $\begin{array}{l}\text { 4. "Objects of geography studies, } \\
\text { principles and concepts needed } \\
\text { in interpreting the location of } \\
\text { observation" }\end{array}$ & $\begin{array}{l}\text { 4. Understanding of } \\
\text { phenomena can be } \\
\text { analyzed with } \\
\text { geographic concepts }\end{array}$ \\
\hline & & $\begin{array}{l}\text { 5. "Group collaboration is needed } \\
\text { to study geographic phenomena } \\
\text { in an integrated manner" }\end{array}$ & $\begin{array}{l}\text { and principles } \\
\text { 5.Collaboration with key } \\
\text { field practice teams }\end{array}$ \\
\hline & & $\begin{array}{l}\text { 6. "The fact is that natural } \\
\text { phenomena affect human } \\
\text { activities at locations around } \\
\text { Bromo Mountain" }\end{array}$ & $\begin{array}{l}\text { 6. Natural and human } \\
\text { phenomena are } \\
\text { interconnected }\end{array}$ \\
\hline & & $\begin{array}{l}\text { 7. "I have difficulty distinguishing } \\
\text { spatial and territorial } \\
\text { approaches in the introduction } \\
\text { of landscape recognition } \\
\text { applications" }\end{array}$ & $\begin{array}{l}\text { 7. The geographical } \\
\text { approach is difficult to } \\
\text { apply in observation }\end{array}$ \\
\hline & & $\begin{array}{l}\text { 8. "Field observations provide } \\
\text { valuable experience because } \\
\text { they demand critical and } \\
\text { scientific thinking" }\end{array}$ & $\begin{array}{l}\text { 8. Feel an experience that } \\
\text { is hard to forget }\end{array}$ \\
\hline 3. & $\begin{array}{l}\text { Achmad Dwi } \\
\text { Kurniawan } \\
\text { (ADK) }\end{array}$ & $\begin{array}{l}\text { 1. "Geography literacy means } \\
\text { understanding natural and } \\
\text { human phenomena, location, } \\
\text { place and region" }\end{array}$ & $\begin{array}{l}\text { 1. Assessing the } \\
\text { location and place } \\
\text { requires geographic } \\
\text { literacy skills }\end{array}$ \\
\hline & & 2. "I think geography literacy is & 2. Geography literacy is \\
\hline
\end{tabular}




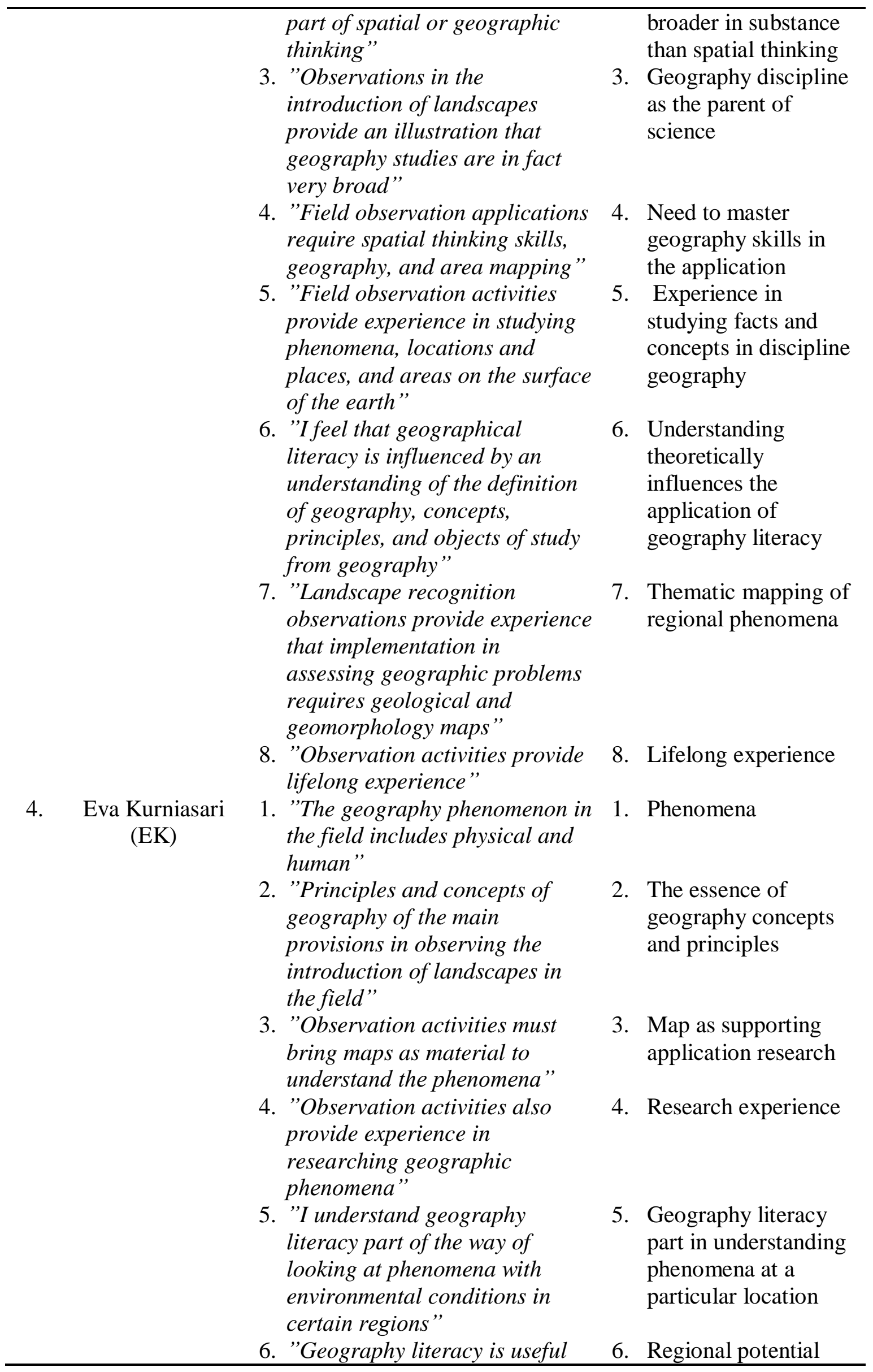




\begin{tabular}{|c|c|c|c|}
\hline & & $\begin{array}{l}\text { for studying regional potential" } \\
\text { 7. "Introduction to the landscape } \\
\text { provides an overview of the } \\
\text { geosphere study as a whole" } \\
\text { 8. "I understand the concepts and } \\
\text { principles of geography after } \\
\text { the field observation } \\
\text { application" }\end{array}$ & $\begin{array}{l}\text { can be analyzed by } \\
\text { geography literacy } \\
\text { 7. Geosphere study } \\
\text { 8. Concepts and } \\
\text { principles are easy to } \\
\text { understand through } \\
\text { practical learning }\end{array}$ \\
\hline \multirow[t]{8}{*}{5.} & $\begin{array}{l}\text { Aisyah Widatul } \\
\text { Khoiroh (AWK) }\end{array}$ & $\begin{array}{l}\text { 1. "Geography literacy part of } \\
\text { understanding phenomena in } \\
\text { the field" }\end{array}$ & $\begin{array}{l}\text { 1. Phenomena part of } \\
\text { geography literacy }\end{array}$ \\
\hline & & $\begin{array}{l}\text { 2. "Geography literacy forms the } \\
\text { use of geographic concepts and } \\
\text { principles in analyzing cases in } \\
\text { the field" }\end{array}$ & $\begin{array}{l}\text { 2. Concepts and } \\
\text { principles of } \\
\text { geography literacy } \\
\text { analysis }\end{array}$ \\
\hline & & $\begin{array}{l}\text { 3. "I feel that field observation } \\
\text { activities are easier to } \\
\text { understand the essence of } \\
\text { geography" }\end{array}$ & $\begin{array}{l}\text { 3. The essence of } \\
\text { geography is easy to } \\
\text { learn }\end{array}$ \\
\hline & & $\begin{array}{l}\text { 4. "I think geography literacy is } \\
\text { useful in building spatial } \\
\text { thinking in studying the region" }\end{array}$ & $\begin{array}{l}\text { 4. Geography literacy } \\
\text { relates to the region }\end{array}$ \\
\hline & & $\begin{array}{l}\text { 5. "Essential geography literacy } \\
\text { skills in location observation" }\end{array}$ & $\begin{array}{l}\text { 5. Literacy skills in } \\
\text { assessing location }\end{array}$ \\
\hline & & $\begin{array}{l}\text { 6. "The experience of geographic } \\
\text { literacy can be seen from the } \\
\text { way of spatial thinking" }\end{array}$ & 6. Spatial thinking \\
\hline & & $\begin{array}{l}\text { 7. "Ifeel the observation of more } \\
\text { landscape recognition activities } \\
\text { to study regional phenomena" }\end{array}$ & $\begin{array}{l}\text { 7. Assessing regional } \\
\text { phenomena } \\
\text { specifically }\end{array}$ \\
\hline & & $\begin{array}{l}\text { 8. "Regional mapping needs to } \\
\text { build geographic literacy" }\end{array}$ & 8. Region mapping \\
\hline \multirow[t]{5}{*}{6.} & $\begin{array}{l}\text { Moh. Fajar } \\
\text { Septarianto } \\
\quad \text { (MFS) }\end{array}$ & $\begin{array}{l}\text { 1. "Geography literacy skills are } \\
\text { useful in understanding all } \\
\text { phenomena in the area of } \\
\text { Bromo Mountain" }\end{array}$ & $\begin{array}{l}\text { 1. Phenomena part of } \\
\text { geography literacy }\end{array}$ \\
\hline & & $\begin{array}{l}\text { 2. "I feel the logic of geography } \\
\text { thinking is needed in studying } \\
\text { phenomena" }\end{array}$ & $\begin{array}{l}\text { 2. Interpretation } \\
\text { phenomena requires } \\
\text { geography thinking }\end{array}$ \\
\hline & & $\begin{array}{l}\text { 3. "I find it very difficult to } \\
\text { develop geography literacy } \\
\text { thinking skills" }\end{array}$ & $\begin{array}{l}\text { 3. Difficulties applying } \\
\text { geography literacy }\end{array}$ \\
\hline & & $\begin{array}{l}\text { 4. "As a geographer I feel the } \\
\text { need for spatial thinking and } \\
\text { literacy skills in studying the } \\
\text { region" }\end{array}$ & $\begin{array}{l}\text { 4. Provision of } \\
\text { geographers includes } \\
\text { spatial thinking skills } \\
\text { and geography }\end{array}$ \\
\hline & & $\begin{array}{l}\text { 5. "Natural and physical } \\
\text { phenomena are easy to learn as } \\
\text { a geosphere study" } \\
\text { 6. "Field observations provide }\end{array}$ & $\begin{array}{l}\text { literacy } \\
\text { 5. Geosphere study }\end{array}$ \\
\hline
\end{tabular}




\begin{tabular}{|c|c|c|c|}
\hline & & $\begin{array}{l}\text { experience in looking at the use } \\
\text { of geography concepts" } \\
\text { 7. "Geography thinking, analysis } \\
\text { and application skills are } \\
\text { needed in building geography } \\
\text { literacy" } \\
\text { 8. "I find it a valuable experience } \\
\text { that landscape recognition } \\
\text { observations provide an } \\
\text { illustration that geography } \\
\text { studies the region supported by } \\
\text { maps" }\end{array}$ & $\begin{array}{l}\text { 6. Application of the } \\
\text { concept of geography } \\
\text { 7. Geography literacy is } \\
\text { influenced by } \\
\text { individual skills in } \\
\text { analyzing and } \\
\text { applying study } \\
\text { geography } \\
\text { 8. Mental experience } \\
\text { map to study the } \\
\text { region }\end{array}$ \\
\hline 7. & $\begin{array}{c}\text { Shandy Choirul } \\
\text { Fatah (SCF) }\end{array}$ & $\begin{array}{l}\text { 1. "Ifeel geography literacy is } \\
\text { useful in analyzing regions such } \\
\text { as Bromo Mountain" } \\
\text { 2. "Field observation activities } \\
\text { provide an overview of } \\
\text { geography phenomena" } \\
\text { 3. "Geography literacy requires } \\
\text { understanding geographic } \\
\text { concepts and principles" } \\
\text { 4. "Geography literacy skills are } \\
\text { useful in analyzing phenomena } \\
\text { and regions as a whole" }\end{array}$ & $\begin{array}{l}\text { 1. Geography literacy to } \\
\text { study the region } \\
\text { 2. Geography } \\
\text { phenomena } \\
\text { 3. Application of } \\
\text { geography concepts } \\
\text { and principles } \\
\text { 4. Analysis of regional } \\
\text { studies requires } \\
\text { individual geography } \\
\text { literacy skills }\end{array}$ \\
\hline 8. & $\begin{array}{c}\text { Arum } \\
\text { Cahyaning } \\
\text { Utami (ACU) }\end{array}$ & $\begin{array}{l}\text { 1. "Ifeel that geographical } \\
\text { literacy not only means studying } \\
\text { location, but also places, } \\
\text { relationships, activities, and } \\
\text { regions" } \\
\text { 2. "Implementation of geographic } \\
\text { literacy requires geography } \\
\text { thinking skills, geographic } \\
\text { analysis, and geography } \\
\text { applications,"” } \\
\text { 3. The observation of the } \\
\text { introduction of landscape in the } \\
\text { Bromo Mountain area is more } \\
\text { on understanding the concepts, } \\
\text { principles and objects of } \\
\text { geography study" } \\
\text { 4. "The geosphere phenomena has } \\
\text { various forms in fact in the } \\
\text { field" }\end{array}$ & $\begin{array}{l}\text { 1. The study of } \\
\text { geography literacy } \\
\text { interpretation the } \\
\text { location and place, } \\
\text { the relationship of } \\
\text { natural and human } \\
\text { phenomena in certain } \\
\text { regions } \\
\text { 2. Geography literacy } \\
\text { skills } \\
\text { 3. Understanding of the } \\
\text { concepts, principles } \\
\text { and object of } \\
\text { geography studies } \\
\text { 4. The form and facts of } \\
\text { the geosphere } \\
\text { phenomena at the } \\
\text { observation site }\end{array}$ \\
\hline
\end{tabular}

Based on the findings in matrix I, we can find the following propositions as follows. The practice geography literacy through field observations includes studies of phenomena, locations, places, interactions, activities, and environments for regional studies. The application of geography literacy needs to be supported by spatial thinking skills, analytical 
thinking, and application of geography for prospective geographers. The essence of geographic concepts and principles is needed in contextual practice supported by maps as a support to understand geography literacy. Landscape recognition observation activities provide experience for prospective geographers in interpretation geographic locations and phenomena in the spatial, environmental and territorial viewpoints for certain places on the earth's surface. In research the application of geographic concepts and principles plays a role in building the dynamics of geographic literacy, especially with the support of geographic skills.

Table 2: The Student Experience of Result Observation the Introduction Landscapes in Bromo Mountains Probolinggo Regency

\begin{tabular}{|c|c|c|c|}
\hline No. & $\begin{array}{c}\text { Name of } \\
\text { Informant }\end{array}$ & Information & The Theme Found \\
\hline \multirow[t]{4}{*}{1.} & $\begin{array}{c}\text { Rislianta } \\
\text { Alsabila (RA) }\end{array}$ & $\begin{array}{l}\text { 1. "Understanding concepts and } \\
\text { theories is easier with field } \\
\text { observation learning } \\
\text { activities" }\end{array}$ & $\begin{array}{ll}\text { 1. Learning } \\
\text { observation }\end{array}$ \\
\hline & & $\begin{array}{l}\text { 2. "I feel the introduction of the } \\
\text { landscape provides a valuable } \\
\text { knowledge experience in } \\
\text { understanding phenomena, } \\
\text { locations, activities, and } \\
\text { regions" }\end{array}$ & $\begin{array}{l}\text { 2. Experience and } \\
\text { knowledge about the } \\
\text { essence of location, } \\
\text { place and region }\end{array}$ \\
\hline & & $\begin{array}{l}\text { 3. "I think that field observation } \\
\text { activities are very helpful in } \\
\text { critical research and thinking } \\
\text { skills" }\end{array}$ & $\begin{array}{l}\text { 3. Research and critical } \\
\text { thinking skills in } \\
\text { field learning }\end{array}$ \\
\hline & & $\begin{array}{l}\text { 4. "Field observation activities } \\
\text { provide experience in building } \\
\text { geographical understanding } \\
\text { for prospective geographers" }\end{array}$ & 4. Geographical skills \\
\hline \multirow[t]{3}{*}{2.} & $\begin{array}{c}\text { Cindy Eka } \\
\text { Pratiwi (CEP) }\end{array}$ & $\begin{array}{l}\text { 1. "Learning field observation is } \\
\text { more interesting in providing } \\
\text { experiences to build geography } \\
\text { thinking" }\end{array}$ & $\begin{array}{l}\text { 1. The experience of } \\
\text { applying geography } \\
\text { thinking in the field }\end{array}$ \\
\hline & & $\begin{array}{l}\text { 2. "The way of thinking in } \\
\text { geography in my opinion } \\
\text { includes the study of } \\
\text { phenomena, location, place, } \\
\text { activity, environment, and } \\
\text { region", }\end{array}$ & $\begin{array}{l}\text { 2. The experience } \\
\text { geography thinking }\end{array}$ \\
\hline & & $\begin{array}{l}\text { 3. "I think field observation } \\
\text { activities provide experience in } \\
\text { examining physical and human }\end{array}$ & $\begin{array}{l}\text { 3. Research experience } \\
\text { through observation } \\
\text { learning activities }\end{array}$ \\
\hline
\end{tabular}




\begin{tabular}{|c|c|c|c|}
\hline & & $\begin{array}{l}\text { phenomena as part of the } \\
\text { analysis and application of } \\
\text { geography" } \\
\text { 4. "Ifeel the field observation } \\
\text { activities train in scientific } \\
\text { thinking, especially in writing } \\
\text { field practice reports and } \\
\text { making scientific articles" }\end{array}$ & $\begin{array}{l}\text { 4. The scientific } \\
\text { thinking skills }\end{array}$ \\
\hline \multirow[t]{6}{*}{3.} & $\begin{array}{l}\text { Achmad Dwi } \\
\text { Kurniawan } \\
\text { (ADK) }\end{array}$ & $\begin{array}{l}\text { 1. "Observation activities give } \\
\text { me more contextual experience } \\
\text { than learning in class" }\end{array}$ & $\begin{array}{l}\text { 1. Contextual learning } \\
\text { experience }\end{array}$ \\
\hline & & $\begin{array}{l}\text { 2. "The practice of field lecture } \\
\text { observation learning provides } \\
\text { an overview of phenomena } \\
\text { formed due to the activity in } \\
\text { certain areas" }\end{array}$ & $\begin{array}{l}\text { 2. The essence of } \\
\text { geography to study } \\
\text { the region }\end{array}$ \\
\hline & & $\begin{array}{l}\text { 3. 'I feel that the practice of } \\
\text { introducing landscape } \\
\text { recognition provides } \\
\text { understanding and knowledge } \\
\text { about phenomena, location, } \\
\text { place, interrelationships, } \\
\text { activities within the scope of } \\
\text { territory" }\end{array}$ & $\begin{array}{l}\text { 3. Understanding and } \\
\text { knowledge of } \\
\text { geography } \\
\text { disciplines about } \\
\text { location, place, } \\
\text { environment and } \\
\text { region }\end{array}$ \\
\hline & & $\begin{array}{l}\text { 4. "I have more motivated in } \\
\text { studying geography, especially } \\
\text { related to integrated } \\
\text { geography" }\end{array}$ & $\begin{array}{l}\text { 4. The motivation to } \\
\text { learn geography }\end{array}$ \\
\hline & & $\begin{array}{l}\text { 5. "I feel observation activities } \\
\text { provide valuable experience in } \\
\text { researching and field testing" }\end{array}$ & $\begin{array}{l}\text { 5. The experiences of } \\
\text { research and testing } \\
\text { in natural }\end{array}$ \\
\hline & & $\begin{array}{l}\text { 6. "Observation activities at } \\
\text { Bromo Mountain help in } \\
\text { scientific thinking which is } \\
\text { realized in the form of } \\
\text { practicum reports and } \\
\text { scientific articles" }\end{array}$ & $\begin{array}{l}\text { laboratories } \\
\text { The geographical } \\
\text { scientific thinking } \\
\text { skills }\end{array}$ \\
\hline \multirow[t]{3}{*}{4.} & $\begin{array}{c}\text { Eva Kurniasari } \\
(\mathrm{EK})\end{array}$ & $\begin{array}{l}\text { 1. "I have real experience related } \\
\text { to the essence of geography } \\
\text { which includes phenomena, } \\
\text { locations, places, activities, } \\
\text { relationships, environment and } \\
\text { regions" }\end{array}$ & $\begin{array}{l}\text { 1. The substance } \\
\text { studies discipline } \\
\text { geography }\end{array}$ \\
\hline & & $\begin{array}{l}\text { 2. "I feel that spatial thinking } \\
\text { skills are more easily applied } \\
\text { in the field directly than } \\
\text { through classroom learning" }\end{array}$ & $\begin{array}{l}\text { 2. The benefits of } \\
\text { practical learning in } \\
\text { the field }\end{array}$ \\
\hline & & $\begin{array}{l}\text { 3. "Research activities train } \\
\text { geography skills especially in } \\
\text { analyzing physical and human }\end{array}$ & $\begin{array}{l}\text { 3. The competence and } \\
\text { skills to examine } \\
\text { geographical }\end{array}$ \\
\hline
\end{tabular}




\begin{tabular}{|c|c|c|c|c|}
\hline & & $\begin{array}{l}\text { phenomena specifically" } \\
\text { 4. "The experience of observation } \\
\text { activities motivates me to apply } \\
\text { geography concepts, principles } \\
\text { and perspectives in studying } \\
\text { the region for all geography } \\
\text { learning" }\end{array}$ & 4. & $\begin{array}{l}\text { problems } \\
\text { Motivation } \\
\text { implementation of } \\
\text { concept, principle } \\
\text { and perspective in } \\
\text { studying geography }\end{array}$ \\
\hline \multirow[t]{4}{*}{5.} & $\begin{array}{l}\text { Aisyah Widatul } \\
\text { Khoiroh (AWK) }\end{array}$ & $\begin{array}{l}\text { 1. "Field observation learning } \\
\text { provides an experience that is } \\
\text { not easily forgotten" }\end{array}$ & 1. & $\begin{array}{l}\text { Life-long experience } \\
\text { with contextual field } \\
\text { observation }\end{array}$ \\
\hline & & $\begin{array}{l}\text { 2. "More observation activities } \\
\text { use geographic analysis skills" }\end{array}$ & & $\begin{array}{l}\text { The experience } \\
\text { analytical skills }\end{array}$ \\
\hline & & $\begin{array}{l}\text { 3. "The first landscape } \\
\text { recognition research } \\
\text { experience for me" }\end{array}$ & 3. & $\begin{array}{l}\text { The experience } \\
\text { research }\end{array}$ \\
\hline & & $\begin{array}{l}\text { 4. "Observation practices critical } \\
\text { and scientific thinking skills so } \\
\text { that I am very motivated to be } \\
\text { a geographer in analyzing } \\
\text { facts and cases at Bromo } \\
\text { Mountain" }\end{array}$ & 4. & $\begin{array}{l}\text { Geographers need } \\
\text { critical and scientific } \\
\text { thinking skills in } \\
\text { studying phenomena }\end{array}$ \\
\hline \multirow[t]{5}{*}{6.} & $\begin{array}{l}\text { Moh. Fajar } \\
\text { Septarianto } \\
\quad \text { (MFS) }\end{array}$ & $\begin{array}{l}\text { 1. "Landscape recognition } \\
\text { observation activities provide } \\
\text { experience in testing, } \\
\text { measuring, researching and } \\
\text { analyzing geographic } \\
\text { phenomena" }\end{array}$ & 1. & $\begin{array}{l}\text { The experience of } \\
\text { field observation } \\
\text { learning }\end{array}$ \\
\hline & & $\begin{array}{l}\text { 2. "Group collaboration is } \\
\text { important in collaborative } \\
\text { observation in the field" }\end{array}$ & 2. & $\begin{array}{l}\text { Learning } \\
\text { collaboration }\end{array}$ \\
\hline & & $\begin{array}{l}\text { 3. "Landscape recognition } \\
\text { observations provide first time } \\
\text { experience while studying } \\
\text { geography in applications" }\end{array}$ & 3. & $\begin{array}{l}\text { The experience } \\
\text { geography learning } \\
\text { applications }\end{array}$ \\
\hline & & $\begin{array}{l}\text { 4. "In my opinion, the } \\
\text { application of concepts, } \\
\text { principles, and point of view of } \\
\text { geography is easier in the } \\
\text { introduction of landscape } \\
\text { recognition applications in } \\
\text { Bromo Mountain" }\end{array}$ & 4. & $\begin{array}{l}\text { The geography } \\
\text { applications are } \\
\text { easier to apply } \\
\text { directly in the field }\end{array}$ \\
\hline & & $\begin{array}{l}\text { 5. "I am as } r \text { geographers } \\
\text { requires an understanding of } \\
\text { the way of geography thinking } \\
\text { in its entirety which includes } \\
\text { understanding the } \\
\text { phenomenon, location and } \\
\text { place, activities, relationships, } \\
\text { spatial, environmental, and } \\
\text { territories as a whole" }\end{array}$ & 5. & $\begin{array}{l}\text { The geography } \\
\text { thinking for } \\
\text { geographs includes } \\
\text { phenomena, } \\
\text { locations and places, } \\
\text { and regions }\end{array}$ \\
\hline
\end{tabular}


6. "Field observation activities provide an overview to me in developing thematic maps such as geological maps, geomorphology and land suitability"

7. "Observation activities require students to be more active, think critically, and think scientifically in analyzing problems in the field"

7. Shandy Choirul 1. "Observation activities give Fatah (SCF)

8. Arum Cahyaning Utami (ACU) geography applications with me more lifelong experience in studying geography"

2. 'I see geosphere studies need each layer to have a relationship in its application in the field"

3. "Field observation activities provide me with the experience of testing and research both physical and human aspects for the first time"

4. "I look at the results of more observations on applications in the interpretation of phenomena, location, place, interaction and interrelation, activity, environment, and territorial"

5. "Ifeel that observation activities require geography thinking, analysis, and cartographic support"

1. "Observation activity on Mount Bromo is the first experience of research in studying geography for me in analyzing location and region"

2. "Understanding geography studies is easier by application through field observation practices compared to theories in classroom learning"

3. "I feel that observation activities are easier to translate into maps supported by scientific reports"

4. "Ifeel that group
6. Making thematic maps from field measurements

7. Student activity for critical and scientific thinking in observation learning

1. The experience of lifelong learning

2. The relations between the layers of the geosphere

3. The first experience of trials and research

4. The field observations of application geography disciplines in location and place, environment and region

5. The geography skills require maps as a medium of interpretation

1. The experience geography research

2. The advantages of observation learning with field practice

3. The results of observation learning with scientific reports supported by mapping the area 


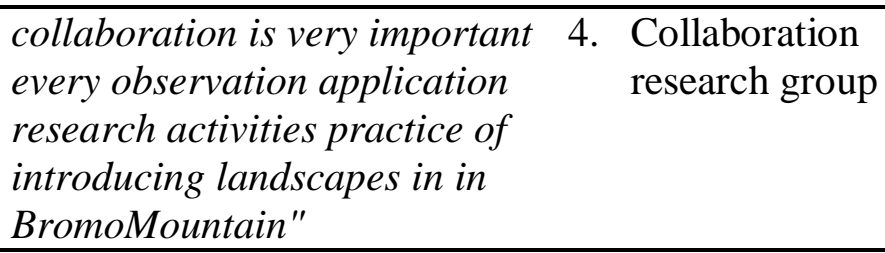

Based on the form of student experience as in matrix II new prepositions can be built. Landscape recognition observation activities provide experience for students throughout life in representing a place. Observation learning is very interesting to be applied directly in the field for geography disciplines. The applications of observation learning provide learning motivation for students to think critically and scientifically in interpreting geography phenomena. Observation serves to provide a research learning experience in constructing geographic thinking for each individual geographer contextually. Trial and measurement activities from observation activities are useful in the preparation of scientific reports and mapping of the area. Location and place need cartographic assistive science to interpret phenomena in studying the region.

The experience of students from observation activities has a function in building skills and thinking geography. Geography skills representation of the competencies expected activities by students in observation introduction landscape. Students as geographers will get new information as result of observation activities. The new information is knowledge for students which is useful for building a geographic thinking perspective.

Understanding of views about geography from more observational activities on scientific attention. The interpretation of the concept of landscapes and culture provides special strength in building spatial understanding for students. The findings Minca (2013), explained that the concept of landscape was at the core of scientific attention from generation to generation from geographers. The nature of geography with the power of phenomena and landscape provides knowledge in understanding the relationship of spatial theory and spatial analysis expressed from spatial systems. Conceptually understanding geographic phenomena can be easily understood as a whole according to the results of the reflection of the observation of the introduction of landscapes in the field. Understanding of natural and human relations is needed by geographers with survey activities and descriptions as an alternative in studying the potential of place and location (Boogaart, 2001).

Field observations affect the learning experience in particular student psychology in the field. Aspects of field experience will influence the development of cognitive, affective, and psychomotoric dimensions of students' thinking. The findings of Boyle, et al. (2007), 
aspects of field learning will have an impact on student affective development which includes attitudes, motivation, and feelings. The development of psychology of students provide to experience in geography studies both in theoretical learning in the classroom and in field applications through landscape recognition activities.

The spatial thinking of students has a relationship with the role of geography literacy improving for understanding the geographical concept of "sense of place". Geography literacy give students more insight into: analysis of location, place, relationship, activity, environment, and region. The dynamics of increasing geographic literacy in K-12 challenge students to deepen geographical knowledge. Thinking geographically provides a connection between humans and places of contact with events, cases and facts from geographic phenomena. The findings Hunter (2016), geography literacy is more effective in interacting and collaborating among students to broaden experiences in different environments. Geography literacy provides an overview of phenomena as problem solving skills and motivating students. The view of geographic literacy information cannot be transferred in proving the phenomena that is examined directly in a particular place and location. The findings of Johnston and Webber (2003), the emphasize landscape learning requires maps in interpreting physical and social aspects of relationships. Information obtained by students is useful in exploring the geographic literacy of both the theory and practice of landscapes with contextual skills (Lyold, 2006).

Geographical literacy skills of each individual student can be ascertained differently despite conducting joint observation activities in groups. The findings Ottati (2015), that exploration of learning can provide different experiences related to geography literacy, attitudes, and experiences according to K-12. Experience in representing the place obtained by students after conducting observation activities is to train research skills, trial, survey, critical thinking, scientific thinking, and thematic map making. The findings Comber (2017), geography literacy has a relationship between pedagogic, social skills, geography, and poverty to build a culture of shared learning in the world of education. Student experience from observation in the form of lifelong learning, pedagogic development, geography skills, research skills, critical and scientific thinking, and writing scientific reports and articles. This experience shows that observation activities generate new knowledge can shape thinking patterns for students as geographers in landscape recognition practice activities. 


\section{Conclussion}

Geography literacy is easier to apply directly in the field with practical learning activities. Students as geographers experience lifelong experiences that are difficult to forget. The experience gained includes the implementation of concepts and principles in the field, measurement, trials, surveys, and research learning. The number of experiences spurred students to develop geographic ways of thinking represented or described from the location and place observed.

Student activities in the field require thinking, analysis, and applications geography especially in studying the region. These skills will build the pedagogical dimension of students in analyzing all aspects of literacy which include: phenomena, place, relationship, activities, environment, and region. All these aspects will give a description of the place in a particular area or what is known as "sense of place". Students as geographs are motivated to think critically and scientifically in solving problems in areas that are the target of the introduction of landscape recognition in Bromo Mountain, Probolinggo regency. The natural and human phenomena studied were realized in the form of regional mapping. The aim is to describe all the problems and phenomena that exist in the observation location of landscape recognition. The application of observation activities needs to be mentally supported by each student so that it is easy to describe and analyze the problems faced. Thus, geographic literacy and skills thinking geography of students are useful to interpretation places and locations that are realized through mapping the area. The result is an analysis of both natural and human potential found in the area of observation activities.

\section{References}

Bogdan, R. And Biklen, S.K.(1998). Qualitative Research for Education: An introduction to theories and methods. Boston: Allyn and Bacon, Inc.

Boogart II, Thomas A. (2001). The Powwer of Place: From Semiotics to Ethnogeography, Middle States Geograher, 2001, 34: 38-47.

Boyle, A., Maguire, S., Martin, A., Milsom, C., Nash, R., Rawlinson, S., Turner, A., Wurthmann, S. \& Conchie, S.(2007). Fieldwork is Good: The Student Perception and the Affective Domain, Journaal of Geography in Higher Education, 31(2), 299317.

Chappell, Adrian.(2007). Using Teaching Observations and Reflective Practice to Challenge Conventions and Conceptions of Teaching in Geography, Journal of Geography in Higher Education, 32(2), 257-268.

Comber, Barbara.(2017). Literacy Geography and Pedagogy: Imagining Translocal Research Alliances for Educational Justice, Journal Literacy Research: Theory, Method, and Practice, Sagepub, University of South Australia, 66, 53-72.

Cotton, Debby R.E., Stokes, Alison, \& Cotton, Peter A.(2010).Using Observational Methods to Research the Student Experience, Journal of Geography in Higher Education, 34(3), 463-473. 
Denzin, Norman K. And Lincoln Yvonna S. (2008). Strategies of Qualitative Inquiry. California: Sage Publications, Inc.

Fatchan, Achmad. (2015). Methodology Research Qualitative of Ethnography and Ethnometodology Approaches for Social Sciences. Yogyakarta: Ombak.

Guertin, L., Stubbs, C., Millet, C., Lee, T., \& Bodek, M.(2012). Enchancing Geographic and Digital Literacy with a Student Generated Course Portfolio in Google Earth, Journal of College Science Teaching, 42(2), 32-37.

Hunter, Nancee.(2016). Assesing Sense of Place and Geo-literacy Indicatorc as Learning Outcomes of an International Teacher Professional Development Program, Dissertation, Porland State University.

Johnston, B. And Webber, S. (2003). Information Literacy in Higher Education: a review and case study, Studies in Higher Education, 28 (3), 335-352.

Levinson, S.C.(2003). Space in Language and Cognition: Explorations in Cognitive Disversity. New York: Cambridge University Press.

Lloyd, Annemaree.(2006). Information Literacy Landscapes: an emerging picture, Journal of Documentation, 62 (5), 570-583.

Miles, Matthew B, Huberman, A. Michael, and Saldana, Johnny.(2015). Qualitative Data Analysis A Methods Sourcebook. Thousand Oaks, CA: Sage Publications.

Minca, Claudio.(2013). The Cultural Geographies of Landscape, Hungarian Geographical Bulletin 62(1), 47-62.

National Research Council.(2005). Learning to Think Spatially. GIS as a Support System in the K12 Curriculum. Washington DC: National Research Council and National Academies Press.

Ottati, Daniela F.(2015). Geographical Literacy, Attitudes, adn Experiences of Freshman Students: A Qualitative Study at Florida International University, Dissertation. Miami: Florida International University.

Patton, M.Q.(2002). Qualitative Research and Evaluation Methods (3rd ed.). Thousand Oasks CA: Sage Publications.

Stokes, A. \& Boyle, A.P.(2009). The Undergraduate Geoscience Fieldwork Experience: Influencing Factors and Implications for Learning, in: S.J. Whitmeyer, D.W. Mogk \& E.J. Pyle (Eds) Field Geology Education-Historical Perspectives and Modern Approach, 461, Geological Society of America, 313-321.

Turner, S., \& Leydon, J.(2012). Improving Geography Literacy among First Year Undergraduate Students: Testing the Effectivess of Online Quizzes, Journal of Geography, 111(2), 54-66. 